\title{
Introduction
}

\section{Comics and Adaptation}

\author{
Armelle Blin-Rolland, Guillaume Lecomte \\ and Marc Ripley
}

\begin{abstract}
This introduction to this special issue of European Comic Art on 'Comics and Adaptation' provides a brief overview of the field of adaptation studies, with a particular focus on its considerable developments and expansion since the late $1990 \mathrm{~s}$, as it has moved beyond a comparative novel-to-film approach to centre instead around questions of intertextuality and hypertextuality. This special issue aims to contribute to this field and to the growing body of works on comics and adaptation. The authors explore questions of transnational circulation of visual, narrative and generic motifs (Boillat); heteronormalisation and phallogocentrism (Krauthaker and Connolly); authenticity of drawn events (Lecomte); identity in a stateless minoritised culture (Blin-Rolland); 'high' and popular culture (Blank); reverence in comic adaptations of the literary canon (de Rooy); and documentary and parody (Ripley).
\end{abstract}

Keywords: adaptation, comics, hypertextuality, intermediality, intertextuality, popular culture

The articles in the present edition of European Comic Art stem from a conference that took place at the University of Leicester in April 2014, with the generous funding of the Society for French Studies, the Association for the Study of Modern and Contemporary France, Intellect and Berghahn Journals. ${ }^{1}$ This special issue brings together scholars from Switzerland, the United Kingdom, the Netherlands and Germany to provide a range of perspectives on comics and adaptation in the Francophone (Belgium, France and the bilingual non-state culture

We would like to thank Catriona MacLeod for her help with organising this conference. 
of Brittany), German, Italian and Iberian contexts. It follows from and complements a previous special issue of European Comic Art on comics adaptations of literary works, broadening the scope to look also at comic to film and TV, film to comic, and legend to comic transpositions. ${ }^{2}$ And with this cross-media focus, our articles are in dialogue with two previous special issues of this journal, on the engagement of comics with other arts and on comics and fine art. $^{3}$

The present edition therefore makes a contribution to adaptation studies, and before we delve into our articles, it is useful to sketch out a very succinct overview of the field. Adaptation studies have expanded and developed considerably since the late 1990s, moving beyond and away from concerns with fidelity to the source text and a comparative approach focused on the novel-to-film format. Scholars such as Robert Stam, Kamilla Elliot, Linda Hutcheon, Julie Sanders, Thomas Leitch, Deborah Cartmell and Imelda Whelehan have reshaped the field around questions of intertextuality and hypertextuality. ${ }^{4}$ They rethought the relationship between source text and adaptation by positing adaptations as 'second without being secondary's and by drawing on the Genettian concept of the palimpsest and on the post-structuralist idea of an 'ever-expanding network of textual relations'. ${ }^{6}$ The recent edited volume Adaptation Studies: New Challenges, New Directions is representative of the continuing evolution of the field. It further explores adaptation as a cultural phenomenon; posits the necessity of understanding adaptation and appropriation as a dialogic process and texts as, to use John Bryant's concept, 'fluid' rather than fixed; and opens up the

2 'Comics Adaptations of Literary Works', European Comic Art 6, no. 1 (2013).

3 'Comics in Dialogue with Other Arts', European Comic Art 6, no. 2 (2013); 'Comics and Fine Art', special issue, European Comic Art 9, no. 2 (2016), guest edited by Hugo Frey and Laurike in 't Veld.

4 See e.g. Brian McFarlane, From Novel to Film: An Introduction to the Theory of Adaptation (Oxford: Clarendon Press, 1996); Robert Stam, 'Beyond Fidelity: The Dialogics of Adaptation', in Film Adaptation, ed. James Naremore (New Brunswick, NJ: Rutgers University Press, 2000), 54-76; Kamilla Elliott, Rethinking the Novel/Film Debate (Cambridge: Cambridge University Press, 2003); Linda Hutcheon, A Theory of Adaptation (New York: Routledge, 2006); Julie Sanders, Adaptation and Appropriation (London: Routledge, 2006); Thomas Leitch, Film Adaptation and Its Discontents: From 'Gone with the Wind' to 'The Passion of the Christ' (Baltimore: Johns Hopkins University Press, 2007); Deborah Cartmell and Imelda Whelehan, Screen Adaptation: Impure Cinema (Basingstoke: Palgrave Macmillan, 2010).

5 Hutcheon, A Theory of Adaptation, 9.

6 Julie Sanders, Adaptation and Appropriation, 3. 
field by turning to texts, such as screenplays, that have not traditionally been examined in adaptation studies.

The dynamism of the field and the fact that it has expanded beyond the unilateral and restrictive literature-to-cinema approach is also evidenced by the growing body of works on comics and adaptation that relocate the debate within the more broadly inclusive concept of intermediality. In particular, examples can certainly be found in edited volumes focusing on adaptation from/into comics and a specific medium, such as Film and Comic Books and Drawn from the Classics: Essays on Adaptations of Literary Works (which is reviewed in this issue), or the French-language Bande dessinée et adaptation (littérature, cinéma, tv), which offers a broader perspective on the dialogue between comics and other media through adaptation (and which includes a chapter on l'effet- $B D$ [the comic book effect] in film by Alain Boillat, who contributes an article to this special issue). ${ }^{8}$ Studying adaptation from and into comics enables us to explore the use of codes and formal resources via an intermedial approach, potentially shedding a new light on the possibilities offered by page layout or text-image relations, for instance. This is echoed in Linda Hutcheon's comment about David Mazzuchelli's graphic novel adaptation of Paul Auster's City of Glass: the 'grid both constrains and enables; it both limits and opens up new possibilities'.? As Robert Stam points out, however, an exclusively formalist and comparative stylistics approach to adaptation 'risks foreclosing a more deeply historical analysis', ${ }^{10}$ and the analysis of a text must take into consideration questions of its context(s), situating adaptations within a broader framework in order to understand them as a cultural phenomenon. These two propositions have now become fundamental concerns

7 Jørgen Bruhn, Anne Gjelsvik and Eirik Frisvold Hanssen, eds, Adaptation Studies: New Challenges, New Directions (London: Bloomsbury, 2013); on the 'fluid text', see John Bryant's chapter, 'Textual Identity and Adaptive Revision: Editing Adaptation as a Fluid Text', 47-68.

8 Ian Gordon, Mark Jancovich and Matthew P. McAllister, eds, Film and Comic Books (Jackson: University Press of Mississippi, 2007); Stephen E. Tabachnick and Esther Bendit Saltzman, eds, Drawn from the Classics: Essays on Graphic Adaptations of Literary Works (Jefferson, NC: McFarland, 2015); Benoît Mitaine, David Roche and Isabelle Schmitt-Pitiot, eds, Bande dessinée et adaptation (littérature, cinéma, tv) (ClermontFerrand: Presses Universitaires Blaise-Pascal, 2015). See Alain Boillat's chapter in this volume, 'L'Effet-BD à l'ère du cinéma en images de synthèse: Quand les adaptations filmiques de comic books suggèrent la fixité de leur modèle dessiné', 179-210.

9 Hutcheon, A Theory of Adaptation, 35.

10 Robert Stam, 'Introduction: The Theory and Practice of Adaptation', in Literature and Film: A Guide to the Theory and Practice of Film Adaptation, ed. Robert Stam and Alessandra Raengo (Oxford: Blackwell, 2005), 1-52 (41). 
of the field and are reflected in our seven articles, as the authors consider media specificity in the transposition from or into comic art, as well as situating their discussion in specific historical, ideological and/ or political national and transnational contexts. In their discussion of the movement of texts across time, media and/or nations, the authors explore questions of transnational circulation of visual, narrative and generic motifs; heteronormalisation and phallogocentrism; authenticity of drawn events; identity in a stateless minoritised culture; 'high' and popular culture; reverence in comics adaptations of the literary canon; and documentary and parody.

The article by Alain Boillat focuses on the relatively little-known editorial context of French-language comics serials for children from the immediate post-war years to the mid-1950s. Boillat examines the prominence of comics adaptations of US films, particularly in the magazines L'Intrépide [The daredevil], which specialised in adaptation, and Le Journal de Tintin. In this context, he highlights the role played by a publishing policy relying partly on the exploitation of North American filmic imaginaries, in a context shaped by the 1949 Law on Children's Publications. The article explores the use of adaptation as a marketing strategy and provides detailed analyses of processes of condensation or amplification of the narrative in comics adaptations, in particular of swashbucklers and westerns, contributing to broader questions of intermedial transfers between comics and cinema.

In their study of Julie Maroh's Le Bleu est une couleur chaude [Blue Is the Warmest Color] and its 2013 film adaptation by Abdellatif Kechiche, La Vie d'Adèle, Marion Krauthaker and Roy Connolly demonstrate how the process of adaptation leads to an alteration of the comic's stance on femininity. Building on Hélène Cixous's reading of the figure of Medusa as a call for female empowerment and radical self-writing, the authors examine how the comic book managed to break free from a gaze traditionally associated with male fantasies regarding female sexuality - a gaze that was arguably reappropriated by Kechiche in a film, Krauthaker and Connolly argue, calling on Roland Barthes's concept of the 'readerly' text, that depicts a heteronormalising, patriarchal and ultimately harmful view of lesbianism and women. For the authors, while the comic gazed at Medusa, at a dangerous and powerful example of femininity, the adaptation is a 'refraction' of its image that perpetuates a phallocentric perspective.

A concern with the differing 'reality effects', in Barthes's term, between source text and adaptation is found in Guillaume Lecomte's 
article. Lecomte examines a rare instance of a non-fiction comic adapted for television: Riad Sattouf's La Vie secrète des jeunes, an illustrated column published in Charlie Hebdo between 2004 and 2014 with a sardonic look at everyday situations its author witnessed involving French young people. Lecomte interrogates claims to truth in Sattouf's comic and its subsequent screen adaptation on Canal+, arguing that, despite the greater degree of indexicality present in the TV series' live-action sequences, the drawn image is better able to represent Sattouf's stories thanks to the narrative and aesthetic modes of representation with which readers of comics are familiar. Examining narrative strategies and paratextual material, Lecomte proposes that Sattouf's comic occupies a seemingly contradictory space that Pascal Lefèvre identifies with factual comics, which derive their sense of authenticity from a specific relational model that relies on the reader's awareness of the constructedness of the graphic image to stand for $a$ view on the reality of a situation.

Armelle Blin-Rolland's contribution strengthens the relationship between postcolonial and comics studies by focusing on two comic adaptations of the Breton legend of the flooded city of Ker-Is. Her article examines two comic 'resurfacings' of the myth, À la découverte de Ker-Is by Robert Lortac (1943) and Claude Auclair and Alain Deschamps's Bran Ruz (1981), works she posits as 'historically situated, and ideologically filtered, views of Bretonness and Brittany'. While the former promotes an ideal Brittany, using its Christian roots and links with other Celtic nations as means of independence propaganda, Bran Ruz ties the legend in with political struggles that disrupted this stateless culture in the 1970s, thus making the comic a political tool for reinforcing Breton identity and criticising the French unitary state. Following Julie Sanders, Blin-Rolland's article further demonstrates that such politicised comic book appropriations participate in the conversation on the legitimacy of the medium within contemporary cultural and ideological contexts.

Although applied to a different national setting, the next article develops a similar argument: Juliane Blank focuses on graphic adaptation in Germany in the context of a still prominent but now narrowing gap between 'high' and 'low' culture. Blank offers an overview of the development of the medium's cultural legitimacy, from the prejudice against comics as Schmutz und Schund [filth and trash] in the 1950s and 1960s to the conception of comics as literature today. She explores the influence of this context on graphic adaptations of novels before 
turning to two recent case studies, Flix's 2009-2010 Faust and Drushba Pankow's 2011 Das Fräulein von Scuderi [Mademoiselle de Scudery]. These two texts, representative of a newly self-confident approach to graphic adaptation, contribute to the debate about 'high' and 'low' culture by reflecting on their own status as graphic adaptations of canonical literature and by deconstructing the respective adapted texts to provide a new interpretation.

In a similar vein, questions of reverence towards the literary canon in comics adaptations are at the heart of Ronald De Rooy's article on Dante's Divina commedia [Divine Comedy]. Surveying key contemporary graphic adaptations of Dante from Europe and the United States, De Rooy examines questions of fidelity to traditional modes of representation - epitomised by Gustave Doré's iconic illustrations - that have typically underscored European adaptations of Dante's Comedy. This reverence towards more conventional styles is contrasted with the rich vein of references from popular North American culture that condition contemporary US adaptations of Dante's work, which see the figure of Dante transmogrified into - among other things - a hoody-wearing teenager and a hard-boiled sleuth. De Rooy highlights the enduring relevance of Dante for the graphic arts in both Europe and the United States, evidenced in his wide-ranging selection of transmedial Dante adaptations, from comics to puppet theatre and video games.

Our concluding article, by Marc Ripley, turns to the Iberian context with an analysis of Fermín Solís's graphic novel Buñuel en el laberinto de las tortugas [Buñuel in the labyrinth of tortoises], which imagines the shooting process of Luis Buñuel's 1933 controversial surrealist documentary, Tierra sin pan [Land without bread]. Ripley shows how Solís uses the medium of comics to expose the relativity of the film's documentary truth, both stylistically (with a particular focus on vocality and the reification of death) and thematically. The article posits this graphic novel as a hypertext performing a transformative parody of both the filmic hypotext and a range of academic and popular sources that perpetuated the discourse of debasement and degeneration seen as a defining characteristic of the region at the time. Solís's graphic text appears to be a unique contribution to the film through its process of demythification of its form and content, ultimately proposing a new reading of Buñuel's Tierra sin pan in a twenty-first-century context.

'The Comic Book Was Better' reads the title of Kyle Meikle's review of Liam Burke's book on the recent lucrative trend of Hollywood adaptations of comics, The Comic Book Film Adaptation: Exploring Modern 
Hollywood's Leading Genre. ${ }^{11}$ Within the contemporary context of the abundance of blockbusters inspired by comic book serials, it is not difficult to imagine - or, indeed, hear - Meikle's title reiterated in the opinions of moviegoers and avid comics readers. However, beyond the undeniable mainstream success of Marvel and DC comic-to-film adaptations, the articles in this special edition demonstrate the considerable flexibility that comics have to offer to the process of adaptation both into and out of the medium. If, as outlined above, adaptation studies as a discipline is now embracing a more capacious interest in intermediality, beyond solely filmic adaptations of literature, the range of articles detailed above reflects the increasing variety of source and target texts that comics are adapted from or that they themselves inspire. Indeed, whilst Henry John Pratt writes that the majority of critical attention given to comics and adaptation has focused on comic-to-film transpositions (in that direction), ${ }^{12}$ this special edition is intended to feed into the growing body of scholarly inquisition within the field of comics studies focused on new directions of intermedial cross-pollination.

Armelle Blin-Rolland is a lecturer in French studies at Bangor University. Her research interests include adaptation from/into literature, bande dessinée and film, Breton comic art and theories of voice across media. She has published articles on these areas in European Comic Art, Studies in French Cinema and Studies in Comics, and book chapters in Adaptation: Studies in French and Francophone Culture (Peter Lang, 2012) and the forthcoming Adapting the Canon (Legenda). Her monograph Adapted Voices: Transpositions of Céline's 'Voyage au bout de la nuit' and Queneau's 'Zazie dans le métro' was published by Legenda in 2015.

Guillaume Lecomte is a PhD candidate in text/image studies at the University of Glasgow. His research started by focusing on the concept of the un-filmable novel, and has now been extended to encompass other media in order to question the issue of unadaptability in the culture industry. He is expected to submit in September 2017. He is also a graduate teaching assistant in the French Department at the University of

11 Kyle Meikle, 'The Comic Book Was Better', Adaptation 9, no. 1 (2015), 113-115; Liam Burke, The Comic Book Film Adaptation: Exploring Modern Hollywood's Leading Genre (Jackson: University of Mississippi Press, 2015).

12 John Henry Pratt, 'Comics and Adaptation', in The Routledge Companion to Comics, ed. Frank Bramlett, Roy T. Cook and Aaron Meskin (London: Routledge, 2017), 230-238 (230). 
Glasgow, where he teaches various language courses, as well as culture, film and comics modules. His research interests include intermediality and adaptation, and repetition in/by the culture industry.

Marc Ripley is a teaching fellow in Spanish and Latin American studies at the University of Leicester, where he designs and teaches courses on Spanish language and cultural studies modules on Hispanic literary and visual arts. He has published articles on Luis Buñuel's films in the Hispanic Research Journal and the Bulletin of Spanish Studies and on director Rodrigo Plá. He is currently writing a book on the Mexican cinema of Luis Buñuel, to be published by Wallflower Press. He is also interested in Hispanic horror cinema and is writing an article on foundation myths of nationhood in Jorge Michel Grau's film Somos lo que hay. 